\title{
A liver with a highly abnormal appearance
}

R A C Dimock, ${ }^{1}$ P Ziprin ${ }^{2}$

${ }^{1}$ Accident and Emergency Department, North West London Hospitals, London, Middlesex, UK

${ }^{2}$ Academic Surgical Unit, Imperial College Healthcare NHS Trust, London, UK

\section{Correspondence to} Dr Richard A C Dimock, richard.dimock@nhs.net

\section{DESCRIPTION}

\section{(a) CrossMark}

To cite: Dimock RAC, Ziprin P. BMJ Case Rep Published online: [please include Day Month Year] doi:10.1136/bcr-2013202544
A 33-year-old man with Crohn's disease presented with 3 days of abdominal pain, bloody diarrhoea and vomiting. He was clinically stable and blood tests showed an isolated $\mathrm{C}$ reactive protein of 81 . Ultrasound (US) scan showed a small air and fluid collection in the right iliac fossa and a highly abnormal liver architecture. An abdominal CT scan was performed (figures 1 and 2).

This showed air within the portal venous system (hepatic portal venous gas, HPVG), tracking up the superior mesenteric vein from a distal ileal mass.

In HPVG the characteristic gas pattern extends to within $2 \mathrm{~cm}$ of the liver capsule, due to centrifugal blood flow, ${ }^{1}$ distinguishing it from pneumobilia, where the centripetal biliary flow results in gas collecting centrally. It is usually diagnosed on CT or US scan, although can occasionally be seen on plain film.

Causes include intestinal necrosis (43-70\%), gastrointestinal dilation (9-12\%), gastrointestinal inflammation (8-16\%), sepsis $(7-11 \%)$ and peptic-ulcer disease $(4 \%){ }^{2}$ The mechanism is either (1) increased intraluminal pressure and mucosal damage, allowing gas to migrate into mural capillaries (as in this case) or (2) gas produced by gasforming bacteria, either from pyelophlebitis in the portal system or from an abscess.

Although there is some evidence to suggest that HPVG can slow or even arrest portal flow, the finding of HVPG should be considered as a diagnostic clue and the underlying aetiology must be identified and treated. Mortality is quoted as $39 \%,{ }^{3}$ rising to $75 \%$ in cases caused by bowel necrosis.

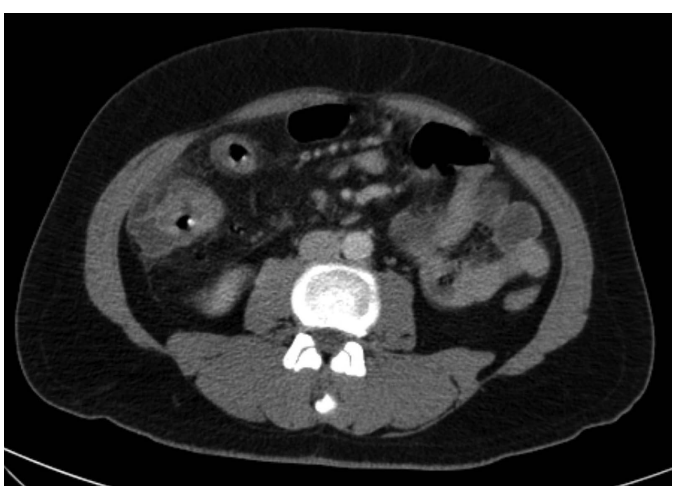

Figure 1 CT scan showing a distal ileal mass, local perforation and air within the venous system.

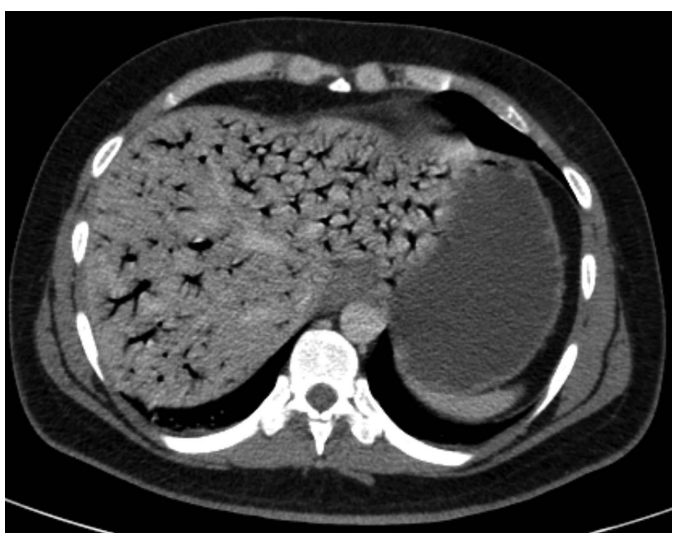

Figure 2 CT scan showing extensive air within the portal system of the liver to within $2 \mathrm{~cm}$ of the capsule.

This patient underwent an open right hemicolectomy and end ileostomy and was discharged 8 days postoperatively.

\section{Learning points}

Hepatic portal venous gas (HPVG) is distinguished from pneumobilia by peripheral gas distribution, extending to within $2 \mathrm{~cm}$ of the liver capsule.

- Bowel ischaemia is the most common cause with mortality of $75 \%$.

- HPVG is not a definitive indication for surgery and management should be directed by the cause; however, an early laparotomy is often needed.

Acknowledgements The authors would like to acknowledge Mr Paul Ziprin.

Competing interests None.

Patient consent None.

Provenance and peer review Not commissioned; externally pee reviewed.

\section{REFERENCES}

1 Kailinia 0, Farid M, Tewari N, et al. Portal venous gas: is it a premorbid indicator? BMJ Case Rep 2011; doi:10.1136/ bcr.07.2010.3206

2 McElvanna K, Campbell A, Diamond T. Hepatic portal venous gasthree non-fatal causes and a review of the literature. U/ster Med J 2012;81:74-8.

3 Kinoshita $\mathrm{H}$, Shinozaki M, Tanimura $\mathrm{H}$, et al. Clinical features and management of hepatic portal venous gas: four case reports and cumulative review of the literature. Arch Surg 2001:136:1410-14. 
Copyright 2014 BMJ Publishing Group. All rights reserved. For permission to reuse any of this content visit http://group.bmj.com/group/rights-licensing/permissions.

BMJ Case Report Fellows may re-use this article for personal use and teaching without any further permission.

Become a Fellow of BMJ Case Reports today and you can:

- Submit as many cases as you like

- Enjoy fast sympathetic peer review and rapid publication of accepted articles

- Access all the published articles

- Re-use any of the published material for personal use and teaching without further permission

For information on Institutional Fellowships contact consortiasales@bmjgroup.com

Visit casereports.bmj.com for more articles like this and to become a Fellow 